\title{
Modern Practice of Military Cultural Awareness: Lithuania among the Great Powers
}

\begin{abstract}
The end of the Cold War marks a changed nature of conflicts - in the modern world, asymmetric wars, counter-insurgencies and counter-terrorism are not only highly relevant threats but also the ones that require perhaps the greatest need for the knowledge of cultural factors. Though the significance of cultural and religious knowledge during international operations is ever more strongly acknowledged, however, the absence of the standardization of cultural awareness of military personnel at NATO level leaves the area of cultural awareness teaching of military personnel participating in international operations the responsibility of national states. This, in turn, exercises influence on countries working in a joint coalition while interpreting, in a different way, the military personnel's cultural awareness and need for it during international operations. The article surveys the diversity of cultural awareness terms and concepts in both academic and military contexts. At the same time, making use of the model of cultural awareness competences formulated by Allison Abbe, the author analyses the manifestation of cultural awareness in the military doctrines and other documents regulating the activity of the armed forces and military service of major NATO states and Lithuania. Lithuania and three major NATO states - the United States, the United Kingdom, and Canada - which have institutionalized cultural awareness teaching of military personnel, have been chosen as the object of the analysis. In this comparative context, the analysis of the Lithuanian case becomes a critical one: it enables one to compare and assess the contribution of a national state to the cultural development of military personnel in the context of major NATO states.
\end{abstract}

\section{Introduction}

The recent three decades mark a change in the mission and tasks of the armed forces. During the Cold War, the essential objective of the armed forces was to guarantee the national interests of states on the grounds of technological achievements and resources; therefore, the perception and cognition of national differences were not a main part of military trainings or exercises. After the Cold War, armies of various states began to be more often involved in

\footnotetext{
*Agniete Žotkevičiūté - Banevičienè is a PhD Candidate and a Lecturer of the Political Science Department of the General Jonas Žemaitis Military Academy of Lithuania. Address for correspondence:

Šilo 5a., LT-10322 Vilnius, tel. (8 5) 2103582, e-mail:. agniete.zotkeviciute@gmail.com
}

DOI: 10.2478/lasr-2018-0005

(C) Agnietė Žotkevičiūtè - Banevičienè, 2018

(C) Military Academy of Lithuania, 2018 
multinational international operations ${ }^{1}$ while asymmetric conflicts, counterinsurgencies and counter-terrorism became not only the most urgent threats but also the ones calling for perhaps the greatest knowledge of cultural factors. ${ }^{2}$ The idea that cultural awareness is a factor that determines the success of international operations was ever more often voiced; for example, the veterans of the International Security Assistance Force (ISAF) stated that the lack of cultural awareness and understanding was the main problem of NATO operations in Afghanistan. ${ }^{3}$

Though the significance of cultural awareness during international operations is more strongly acknowledged, the need for cultural awareness by military personnel is most often assessed, not at the level of NATO, but only at that of national states. NATO organizes certain cultural awareness exercises or includes cultural awareness into teaching programs, for example in Mission Rehearsal Exercises, but these exercises are not standardized. ${ }^{4}$ The Alliance establishes committees and working groups in settling the issue of the standardization of cultural awareness, yet, until now, it was rather a technical action than the aspiration to involve military personnel into the cultural interaction or encourage the cooperation of military personnel at cultural or cultural awareness levels. ${ }^{5}$ The fact that the definition of cultural awareness of military personnel and the standardization of teaching at the NATO level is non-existent enables member states to differently interpret cultural awareness of military personnel and the need for it in international operations. ${ }^{6}$ The watershed among NATO members is also augmented by the fact that states belonging to the Alliance not only differently interpret cultural awareness of military personnel but also implement various decisions pertaining to the training of culturally aware soldiers at different levels. In the United Kingdom, Canada, and the United States of America (further - the USA), cultural awareness is an institutionalized form

\footnotetext{
${ }^{1}$ Wolfgang Z., "Intercultural awareness - a necessary asset of soldiers for international operations", AARMS, Vol. 10, No. 2, 2011, 293-304, http://www.zmne.hu/aarms/docs/Volume10/Issue2/pdf/07.pdf, [2017-08-19].

${ }^{2}$ Wunderle W. D., Through the lens of cultural awareness: a primer for US Armed Forces deploying to Arab and Middle Eastern countries, Fort Leavenworth, Combat Studies Institute Press: Washington, DC, 2006, p. 87.

${ }^{3}$ Kaiser S. S., Intercultural perceptions, master of operational arts and sciences, Air Command and Staff College, Air university, 2016, p. 15.

${ }^{4}$ Assessing the impact of cultural awareness and public perceptions in NATO operations, Seminar held on 24 October 2013, NATO HQ, Report, 11 november 2013.

${ }^{5}$ Implementing Cross-Cultural-Competence Training, http://www.act.nato.int/article-2013-2-18, [2016-11-11].

${ }^{6}$ Multinational Interoperability council coalition building guide, $3^{\text {rd }}$ edition, Volume III.2, Cross-Cultural awareness \& Competence - a Guide to Best Practices, Version 1.1, 07 November 2012, p. 7-9.
} 
of the national Defence system. In other NATO states, cultural exercises are limited - troops are trained only just before leaving for an international operation or the cognition of the cultural context is limited to $\backslash$ preparing and using cultural advisors during international operations. ${ }^{7}$ Thus, the objective of this article is to analyse the manifestation of cultural awareness of military personnel in the military doctrines and other documents regulating the activity of the armed forces of Lithuania and major NATO states that have institutionalized cultural awareness exercises - the USA, the United Kingdom, and Canada.

The article aims at bringing to light the attitude to cultural development of military personnel declared in primary documents of different NATO states - the military doctrines and other documents regulating the activity of the armed forces - without attempting to assess the effectiveness of cultural awareness exercises implemented in practice in each analysed state. In this comparative context, the analysis of the Lithuanian case becomes a critical one: having brought to light common tendencies of the cultural development of military personnel of major NATO states, it is possible to compare the contribution of a national state to the cultural development of military personnel in the context of major NATO states. It is important to draw attention to the fact that although the major NATO states included in the research are linked by a common denominator - they all have institutionalized the cultural development of military personnel - the extent of the involvement of these states in international operations is considerably different - according to the data of 2017, about 210,000 of the armed forces personnel from the USA, ${ }^{8} 9,330$ from the United Kingdom ${ }^{9}$ and 1,450 from Canada ${ }^{10}$ participated in international operations. In Lithuania, up to 140 military personnel participate in different international operations. ${ }^{11}$ Taking into consideration the disparity of the involvement of the analysed states in international operations, the author of the article put

\footnotetext{
${ }^{7}$ Trochowska K., "International Experiences in the Operationalization of Culture for Military Operations. Field Research Results", Connections: The Quarterly Journal, Vol. 13, No. 3, Summer 2014, p. 83-103, p. 87-89.

${ }^{8}$ Fisher M., Pecanha S., "What the U.S. Gets for Defending Its Allies and Interests Abroad", 2017-01-16, https://www.nytimes.com/interactive/2017/01/16/world/trump-military-role-treaties-allies-nato-asiapersian-gulf.html, [2017-12-15].

${ }^{9}$ Ministry of Defence, Quarterly Location Statistics, October 2017, https://www.gov.uk/government/uploads/system/uploads/attachment_data/file/659880/20171115-QLS_Front_Page_Oct17-a.pdf, [2017-12-15].

${ }^{10}$ National Defence, "Tax Exemption for Salaries of Deployed Canadian Armed Forces Personnel and Police Officers", 2017-05-18, https://www.canada.ca/en/department-national-defence/news/2017/05/ tax_exemption_forsalariesofdeployedcanadianarmedforcespersonnela.html, [2017-12-15].

${ }^{11}$ Lietuvos respublikos krašto apsaugos ministerija, „Lietuvos dalyvavimas tarptautinėse operacijose ir mokymo misijose“, 2017-12-01, https://kam.lt/lt/tarptautinis_bendradarbiavimas/tarptautines_operacijos. html, [2017-12-15].
} 
forward the hypothesis that the extent of the involvement of military personnel in international operations has no influence on the regulation of cultural awareness teaching in military doctrines and other documents regulating the activity of the armed forces of major NATO states. The article makes a proviso that cultural awareness of only land forces will be analysed.

The article consists of two parts. In the first part the reader is familiarized with cultural awareness terms and concepts in both academic and military contexts. This section surveys the diversity of the usage of the concept, shortcomings of the attempts to hierarchize concepts covering cultural awareness, and the impact of the activity conducted by military personnel on the multi-dimensionalism of cultural awareness. At the same time, the model of cultural awareness competences formulated by Allison Abbe and enabling her to define the cultural awareness of military personnel participating in international operations is presented. In the second part, the manifestation of cultural awareness in the military doctrines and other documents regulating the activity of the armed forces and military service of the USA, the United Kingdom, Canada and Lithuania is analysed. In summing up the research, common cultural development tendencies and differences of the analysed states are provided and the cultural development of the military personnel of Lithuania is compared in the context of major NATO states.

\section{Terms and Concept of Cultural Awareness}

Cultural awareness is a rather new definition in Lithuanian military and scientific terminology though "nearly two decades ago it became common in American and British terminology after special cultural education (or cultural training) courses were organized and teaching material prepared for military personnel sent to international operations, particularly to Muslim countries". ${ }^{12}$ In trying to define cultural awareness in foreign military terminology, a shortage of cultural awareness usage is noticeable - a diversity of the usage of this term was created by terminology proliferation and absence of scientifically strict limits. ${ }^{13}$ In the academic literature, a great number of terms defining cultural

\footnotetext{
${ }^{12}$ Račius E., „Kultūrinio išprusimo veiksnio iškilimas XXI a. karinëje diplomatijoje“ in Lietuvos karine diplomatija XXI amžiuje: retrospektyva ir perspektyva: mokslinès praktinès konferencijos medžiaga, atsakingasis redaktorius prof. dr. Gediminas Vitkus, Vilnius, 2010 m. gruodžio 3 d., Generolo Jono Žemaičio Lietuvos karo akademija, p. 51-55, p. 51

${ }^{13}$ Selmeski B., Military cross-cultural competence: Core concepts and individual development. Royal Military College of Canada Centre for Security, Armed Forces \& Society Occasional Paper Series, Number 1, 2007, p. 5.
} 
awareness are used. The most frequent are these: cultural adaptability, ${ }^{14}$ cultural expertise,$^{15}$ cultural capability, ${ }^{16}$ cultural intelligence, ${ }^{17}$ cultural sensitivity, ${ }^{18}$ cultural literacy, ${ }^{19}$ cultural awareness, ${ }^{20}$ cultural understanding, ${ }^{21}$ cultural knowledge, ${ }^{22}$ and intercultural competences/cross-country competences. ${ }^{23}$ Despite the abundance of the definitions, the absence of the hierarchism of these terms causes a still greater confusion. On the one hand, some academicians propose not to hierarchize these definitions, for example, Prof. Egdūnas Račius underlines that the terms of cultural awareness, cultural understanding,

\footnotetext{
${ }^{14}$ See: Sutton J. L. ir Gundling E., "Enabling Cultural Adaptability" in Strategies to Maintain Combat Readiness during Extended Deployments - A Human Systems Approach, Meeting Proceedings RTO-MPHFM-124, Paper 12, Neuilly-sur-Seine, France: RTO, 2005, p. 12-1 - 12-10.

${ }^{15}$ See: Wisecarver M. et al., Regional Expertise and Culture Proficiency. Project Report 2012-01, Defense Language and National Security Education Office, September 2012, also Kaczmar S. R., Cultural Expertise and its Importance in Future Marine Corps Operations, Quantico, Virginia: USMC Command \& General Staff College thesis, 1996.

${ }^{16}$ See: Abbe A., Building cultural capability for full-spectrum operations, ARI Study Report 2008-04, Arlington, VA: U.S. Army Research Institute for the Behavioral and Social Science, 2008.

${ }^{17}$ See: Coles J. P., "Cultural Intelligence \& Joint Intelligence Doctrine“, Joint Operations Review, Joint Forces Staff College, 2005, p. 1-14

${ }^{18}$ See: Shamir B. ir Ben-Ari E., "Leadership in an Open Army? Civilian Connections, Interorganizational Frameworks and Changes in Military Leadership" in Hunt J. G., Dodge G. and Wong L. (eds.), Out-of-theBox Leadership: Transforming the Twenty-First-Century Army and Other Top-Performing Organizations, Stamford, Conn.: JAI Press, 1999, p. 15-40.

${ }^{19}$ See: McFarland M., "Military Cultural Education", Military Review, March-April 2005, p. 62-69.

${ }^{20}$ See: Kimmel P. R., "Cultural and Ethnic Issues of Conflict and Peacekeeping" in Harvey J. Langholtz (ed.), The Psychology of Peacekeeping, Westpoint, Connecticut: Praeger, 1998, p. 57-71, also Schwerzel J., „Transforming altitudes.“ NATO Review, Summer 2005. Prieiga internetu http://www.nato.int/docu/review/2005/issue2/english/art3_pr.html, also Skelton I. ir Cooper J., "You’re Are Not From Here, Are You?", Joint Force Quarterly, Issue 36, 2005, p. 12-16, also Wunderle W. D., Through the lens of cultural awareness: a primer for US Armed Forces deploying to Arab and Middle Eastern countries, also Ulibarri W. J., "Cultural Awareness-Winning at the Tactical Level", Infantry, Vol. 97, May-June 2008, p. 2.

${ }^{21}$ See: Bledsoe E. E., The Use of Culture in Operational Planning, also Department of the Army, FM 3-24, Counterinsurgency, Washington: US Army Training and Doctrine Command and Marine Corps Combat Development Command, 2006, also Leslie M. S., "Cultural Understanding: The Cornerstone of Success in a COIN Environment", Infantry, Vol. 96, No. 47, 2007, p. 7-12, also Hernandez P. R., "Developing Cultural Understanding in Stability Operations: A Three Step Process", Field Artillery Journal, January-February, 2007, p. 5-10.

${ }^{22}$ See: Jager S. M., On the Uses of Cultural Knowledge, Strategic Studies Institute, U.S. Army War College, 2007, also Kienscherf M., "Plugging Cultural Knowledge into the U.S. Military Machine: The Neo-Orientalist Logic of Counterinsurgency", Topia, Canadian Journal of Cultural Studies, 2010, p. 121-143.

${ }^{23}$ See: Elron E. et al., "Cooperation and coordination across cultures in the peacekeeping Forces: Individual and Organisational Integrating Mechanisms" in Britt T. T. ir Adler A. B. (eds.), The Psychology of the Peacekeeper, Westpoint, Connecticut: Praeger, 2003, p. 261-282, also Abbe A. et al., Cross-cultural competence in Army leaders: A conceptual and empirical foundation, also Selmeski B., Military cross-cultural competence: Core concepts and individual development, also Abbe A. ir Halpin S. H., "The Cultural Imperative for Professional Military Education and Leader Development", Parameters, Winter 2010, p. 21-31. also Kamorski M. W., A study of the need for cross-cultural capability development in the members of the United States military, magistro darbas, U.S. Army Command and General Staff College, Fort Leavenworth, 2008.
} 
cultural sensitivity, or cultural intelligence can be used as synonyms. ${ }^{24}$ On the other hand, in the academic literature, attempts to hierarchize the afore-mentioned definitions are noted. For example, Victor Bados et al. hierarchize the definitions of cultural awareness, cultural understanding and cultural competences perceiving cultural awareness and cultural understanding as the ability of military personnel to identify and describe the main information about another cultural environment, in other words, to acquire knowledge about another culture, whereas cultural competence is the ability of military personnel to use and synthesize information about another cultural environment - not only to acquire but also to apply knowledge about another culture. The latter concept refers to the ability of military personnel to interpret information, whereas other afore-mentioned ones refer to the ability to repeat the acquired information. ${ }^{25}$ Such individual and incomplete models of the hierarchism of cultural awareness terms preclude creating a comprehensive and hierarchized image of the diversity of this concept. Also, while analysing different terms, one notes that academicians speaking about the same concepts understand them differently as comprising a different spectrum of cultural knowledge.

In the military context, cultural awareness can be defined, in a broad sense, as "the cognizance of cultural terrain for military operations and the connections between culture and war fighting." ${ }^{26}$ Notwithstanding, even here the concept of cultural awareness is devoid of any acceptable standards and depends on definitions used by national states. For example, in the 2016 Military Doctrine of the United Kingdom, cultural awareness of military personnel is divided into three levels which are: cultural awareness, cultural competences and cultural expertise. Cultural awareness is defined as the basic knowledge about the aspects of another culture, understanding of the significance and impact of these aspects and the ability to apply this knowledge seeking the desired effect. Cultural competences are defined as providing advanced-level knowledge about cultural aspects, understanding of their importance and impact, as well as the ability to apply this knowledge, skills, and attitudes. These skills are developed through everyday interaction with another culture through both direct involvement and through interpreters and give high-level competences that can be perfected up to cultural expertise. Cultural expertise

\footnotetext{
${ }^{24}$ Račius E., "The 'Cultural Awareness' Factor in the Activities of the Lithuanian PRT in Afghanistan", Baltic Security \& Defence Review, 2007, Vol. 9, p. 57-78, p. 58.

${ }^{25}$ Bados V. et al., Guidelines for Commanders and Staffs: Operationalization of Culture into Military Operations (Best Practices), Final Report, USJFCOM J9 Joint Concept Development and Experimentation, Suffolk, VA, 2010, p. 8-9.

${ }^{26}$ Multinational Interoperability council coalition building guide, (footnote 6), p. 1-2.
} 
is advanced-level knowledge about cultural aspects of another culture as well as comprehension of the significance and impact of another culture on the local population, skills to tackle unexpected tasks, and the ability to analyse and effectively apply this analysis to the planning of further actions. Cultural expertise is merging with another culture and the ability to reason as representatives of a certain target culture do. ${ }^{27}$

Canadian armed forces also hierarchize cultural awareness of their military personnel dividing it into the levels of cultural competences and cultural awareness: cultural competences are defined as personal qualities, knowledge and skills determining the ability to act effectively in another culture, whereas cultural awareness is defined as a combination of culture-specific and crossculture knowledge. The German Leadership, Development, and Civic Education Center (Zentrum Innere Führung) defines cross-culture competences as the knowledge and the ability to adequately behave with other cultures and religions as well as the development of understanding and sensibility for cultural values and behaviour. ${ }^{28}$ Despite the fact that different states use different terms defining cultural awareness, even in the same state one can encounter the problem of the definition of soldiers' cultural awareness. The armed forces of the USA are often criticized in terms of the lack of standardization of the definition of troops' cultural awareness among different subunits of the armed forces. ${ }^{29}$

Confusion in defining cultural awareness of military personnel is also compounded by the multi-dementionalism of cultural awareness - the need for cultural awareness changes depending on the nature of operations conducted by military personnel and the area of operation..$^{30}$ Though the need for cultural awareness arises while military personnel are still operating in their own cultural environment, encountering military personnel's own demographic differences, and increases while conducting joint activities with coalition forces, running into different army practices, conduct, and the tactics and objectives of international operations, however, the greatest need for cultural awareness

\footnotetext{
${ }^{27}$ United Kingdom Assistant Chief of the Defence Staff. Joint Doctrine Note 1/09: The Significance of Culture to the Military. Wiltshire, UK: Chief of Defence (Development, Concepts and Doctrine), January 2009 , p. $5-22-5.23$.

${ }^{28}$ Multinational Interoperability council coalition building guide, (footnote 6), p. 2-3.

${ }^{29}$ Greene Sands R. R. et al, "Assessing Language, Regional Expertise \& Culture (LREC) Performance: Not like threading a camel through the eye of a needle", http://www.govtilr.org/Publications/Final\%20to\%20 Scott.pdf, [ 201707 08].

${ }^{30} \mathrm{McD}$ onald D. P. et al. Developing and managing cross-cultural competence within the Department of Defense: Recommendations for learning and assessment, Paper submitted to the DLO, Revised October 27,2008 , p. 25-26.
} 
emerges when military personnel conduct an international operation in an environment other than their own. ${ }^{31}$ Cultural awareness of military personnel during international operations can help attract support of the local populace and understand the enemy. On the one hand, socio-cultural knowledge assists military personnel in developing familiar relations with representatives of another culture and encourages locals to contribute to the successful implementation of the international operation. Familiar relations of the military with locals help to enhance the cooperation between military personnel and local inhabitants, enable them to receive the support of the local population for the international operation conducted by military personnel, involve inhabitants in local security initiatives, and enhance the support of the government of the country and the coalition supporting it for the activity performed by military personnel. ${ }^{32}$ On the other hand, cultural awareness can help military personnel to understand the motivation of the enemy, their behavioural models, comprehend the processes of decision-making and the system of values influencing enemy decision-making, identify informational operations and the broadcast propaganda, recognize historical symbols of the country where the international operation is conducted by distinguishing safe areas from places historically preferred for attacks by the enemy - potential targets, and the predicted time - that can be significant in terms of history, religion or ideology, as well as get to know historical alliances or enemy supporters, foreseeing the potential sources of financing, routes of supply, etc. ${ }^{33}$

Though the need for cultural awareness of military personnel participating in international operations is of great importance, compared to the routine military activity of, for example, the functioning of military personnel in their own country, however, Elron Halevy et al. established that cultural awareness teaching of military personnel participating in international operations, covering exceptionally culture-specific competences, i.e. the military personnel acquiring only factual information about the country where an international operation is planned to be conducted, is not sufficient. Such development of soldiers' competences prepares them for an exceptionally tactical-operational level. ${ }^{34}$ The narrowness of culture-specific competences in training military

\footnotetext{
${ }^{31}$ Ibid, p. 25-26.

${ }^{32}$ Spencer E., "Brains and Brawn: Cultural Intelligence (CQ) as the 'Tool of Choice' in the Contemporary Operating Environment”, Canadian Military Journal, Vol. 11, No. 1, 2010, p. 15-23, p. 20.

${ }^{33}$ Ibid, p. 21.

${ }^{34}$ Elron E. et al., "Cooperation and coordination across cultures in the peacekeeping Forces: Individual and Organisational Integrating Mechanisms" in Britt T. T. ir Adler A. B. (eds), The Psychology of the Peacekeeper, Westpoint, Connecticut: Praeger, 2003, p. 262.
} 
personnel for international operations is also underlined by Paula Caligiuri et al. who claim that factual knowledge about the country where an international operation is conducted is not sufficient for cultural awareness of military personnel. Cultural awareness of military personnel participating in international operations should also cover cross-culture competences - the ability of military personnel to adapt to another cultural environment seeking an effective interaction with other military personnel, local population, and coalition allies. ${ }^{35}$ Taking into consideration a specific need for cultural awareness of military personnel while participating in international operations, Allison Abbe distinguished necessary cultural awareness competences of military personnel participating in international operations. These are: cross-culture competences, culture-specific knowledge, and language proficiency (see Figure 1).

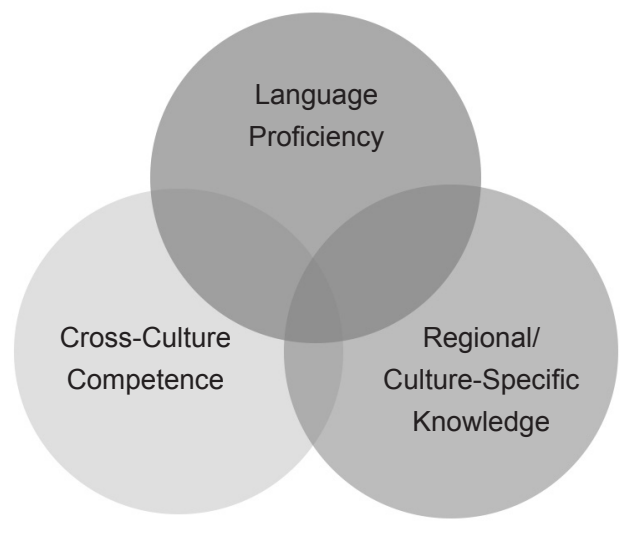

Figure 1. Competences necessary for cultural awareness of military personnel participating in international operations ${ }^{36}$

In the academic literature, the importance of the interaction of crossculture, culture-specific, and language competences for the cultural awareness of military personnel participating in international operations are identified not only by Abbe but also by Stanley H. Halpin and Brian Selmeski, who define culture-specific knowledge ${ }^{37}$ as that of the soldiers knowing what to think, in other words, it is the knowledge about a specific region or culture where the integration operation is conducted. Culture-specific competence is comprised

\footnotetext{
${ }^{35}$ Caligiuri P. et al., Training, Developing, and Assessing Cross-Cultural Competence in Military Personnel. Technical Report 1284, United States Army Research Institute for the Behavioral and Social Sciences, April 2011, p. 6-7.

${ }^{36}$ Source: compiled according to Abbe A., Building cultural capability for full-spectrum operations, (footnote 16), p. 2.

${ }^{37}$ In the academic literature, culture-specific competences are often called regional competences, regional knowledge.
} 
of the knowledge about the economic, religious and historical situation, social infrastructure, local population, policy, national and religious holidays, geographic, and climatic and topographical position of the country where the international operation is conducted. Notwithstanding, the acquisition of culture-specific knowledge does not supply military personnel with the knowledge of how to think in another cultural environment. It is the defining of cross-culture competence as the knowing of military personnel how to think - how to communicate with people of another culture, how to interpret situations, how to adapt one's behaviour seeking the desired results, ${ }^{38}$ it is the ability to accept and understand cultural information enabling one to avoid generalizations, leading to the stereotypical thinking of military personnel..$^{39}$ At the same time language proficiency is also important since it enables military personnel to get involved in social communication in another cultural environment. Though knowing the language of the country where an international operation is conducted grants soldiers the possibility to cross the limits of the observation of culture and cultural differences ${ }^{40}$ the shortage of language skills of military personnel during international operations is compensated for while developing the social interactions of military personal with locals through interpreters. ${ }^{41}$

The synthesis of these three competences is acknowledged by many academicians as suitable for the development of cultural awareness of military personnel participating in international operations. Almost an analogous model of soldiers' cultural awareness is proposed by Prisco R. Hernandez, who distinguishes language skills, academic studies of a certain culture, and practical application of knowledge while being in another cultural environment. ${ }^{42}$ The analysed concepts of cultural awareness and terms used in both academic and military literature make it possible to formulate the definition, that is further used in the article, of the cultural awareness of military personnel participating in international operations: cultural awareness is the knowledge about a certain country, including the economic, religious and historical situation, social infrastructure, local population, policy, national and religious holidays, geographic, climatic and topographical position, and the ability to apply this knowledge while adapting and operating in another cultural environment as

\footnotetext{
${ }^{38}$ See: Abbe A., Building Cultural Capability for Full-spectrum Operations, also Abbe A. ir Halpin S. H., "The Cultural Imperative for Professional Military Education and Leader Development", also Selmeski B., Military Cross-cultural Competence: Core Concepts and Individual Development.

${ }^{39}$ Abbe A., Building Cultural Capability for Full-spectrum Operations, (footnote 16), p. 5-6.

${ }^{40}$ Watson J. R., The Role of Language Proficiency in Cross-cultural Competence (3C): A Fundamental Key to Intercultural Effectiveness in Military Personnel, United States Military Academy, West Point, New York, p. 3.

${ }^{41}$ Wisecarver M. et al., (footnote 15), p. A-5.

${ }^{42}$ Hernandez P. R., (footnote 21), p. 6.
} 
well as skills of the language dominating in the country where the international operation is conducted, the lack of which can be compensated by the skill of working through an interpreter.

\section{The Manifestation of Cultural Awareness of Military Personnel in NATO States}

In this section of the article, the manifestation of cultural awareness is analysed in military doctrines and other documents regulating the activity of the armed forces and military service of the USA, the United Kingdom, Canada, and Lithuania. Seeking to retain the integrity of the analysis, the analysis of the states is carried out by setting these criteria:

- In military doctrines and other documents regulating the activity of the armed forces and military service these items are declared:

- The definition, need and nature of cultural awareness;

- The methods and duration of cultural awareness teaching;

- The differentiation of cultural awareness exercises taking into consideration the activity carried out by military personnel, the positions held and military ranks;

- The interaction of the regulated cultural awareness with cross-culture, culture-specific and language competences identified in the theoretical model and mandatory for the cultural awareness of military personnel participating in international operations;

- Institutional and/or interinstitutional regulation of cultural awareness of military personnel;

- Initiatives enhancing cultural awareness of military personnel that emerged while participating in international operations and/or importing the experience of other states.

\subsection{The Manifestation of Cultural Awareness in the United States of America}

Terrorist attacks and military operations in Afghanistan and Iraq provided grounds for the discussion about the role of cultural competences on the battlefield discovering anew that culture and warfare are interrelated. A great number of high-ranking officers of the USA armed forces who returned from military service in Afghanistan and Iraq, academicians, and foreign po- 
licy professionals began to publish articles escalating the impact of cultural factors on the environment where an international operation is conducted. The inclusion of cultural awareness into the activity of the armed forces drew the support of the White House as well; for example, President Barack Obama, in his speech to war veterans in 2009, emphasized that "in the 21st century, military strength will be measured not only by weapons our troops carry, but by the language they speak and the cultures they understand". ${ }^{43}$

The Military Doctrine "Army Field Manual 3-24: counterinsurgencies", published in 2006, changed the attitude of the armed forces to cultural awareness of military personnel. It was a new type of doctrine fundamentally different from the previous ones in that the primary attention in it was devoted to people. The bases of the Doctrine was the ideas presented in Clausewitz's theory that underlined the importance of people and their expectations in warfare. ${ }^{44}$ The Doctrine emphasizes that "In a COIN environment, it is often counter-productive to use troops that are poorly trained or unfamiliar with operating close to the local populace $<\ldots>$ since COIN forces aim to mobilize the good will of the people against the insurgents. Therefore, the populace must feel protected, not threatened, by COIN forces' actions and operations". ${ }^{4}$ In the Doctrine, great attention is paid to the operationalization of the cultural awareness of military personnel, however standards of cultural exercises or organizational structure are not provided. ${ }^{46}$

Though the ideas of cultural development of military personnel were more loudly voiced in the armed forces, there was still the lack of a strategy for such teaching. 2007 can be considered a break-through point concerning the cultural development of troops: this was the year the Defence Language Office organized the Regional and Cultural Expertise Summit, the aim of which was to identify regional and cultural competences in seeking to understand the needs of international operations and create a framework for the synchronization of policy, plans, and programs complying with current needs. The result of this was the publication, in 2007. of the White Paper of the USA Defence Department, "DoD Regional Capabilities, The Way Ahead", which provided for the actions necessary to undertake seeking to institutionalize cultural exer-

\footnotetext{
43 “Obama’s Address to Veterans", New York Times, 200908 17, http://www.nytimes.com/2009/08/18/us/ politics/18obama.text.html?mcubz=1, [2017-06-17].

${ }^{44}$ Herrman J. J., The Engine of Change: The Evolution of Culture into the Army Planning Process, U.S. Army School of Advanced Military Studies, 2013, p. 9.

${ }^{45}$ Army Field Manual 3-24: Counterinsurgency, United States. Department of the Army, 2006, p. 7-1 - 7-2.

${ }^{46}$ Herrman J. J., (footnote 44), p. 9.
} 
cises of military personnel. ${ }^{47}$ The armed forces then started creating cultural development programs, language and culture centres, and career development models. ${ }^{48}$ One of the first documents related to the development of cultural awareness of troops in the armed forces was the Instruction DodI 5160.70 "Management of Language and Regional Expertise" published by the USA Defence Department in 2007. ${ }^{49}$ At the same time, the USA Army Training and Doctrine Command (TRADOC) was appointed as the executive agent in implementing all the comprehensive decisions covering career development and pre-deployment teaching of foreign cultures and languages. Notwithstanding, decentralized initiatives created a cultural development infrastructure which lacked integrity: individual subunits of the armed forces used a poorly intercoordinated terminology which distinguished different cultural competences; also, the divergence in opinions of different institutions in general hindered the success of cultural exercises. ${ }^{50}$

Taking into consideration the shortcomings of the current cultural development of troops, the Directive 5160.41E "Defence Language, Regional Expertise, and Cultural Program (LREC), issued by the Defence Department in 2005, was changed in 2015 and renewed in 2016. ${ }^{51}$ This program regulates the distribution of functions among different subunits of the armed forces concerning the implementation of the Language, Regional Expertise, and Culture Program..$^{52}$ Renewed in 2016, the Instruction DoDI 5160.70 "Management of the Defence Language, Regional Expertise, and Cultural Program" provides much more accurate standards and competences of the cultural exercises of military personnel. In the program, cultural awareness of military personnel is divided into regional skills that correspond in this instruction to culture-specific and language competences as well as cultural exercises reflecting crossculture competences provided in the theoretical model. Regional skills in the instruction are further divided into six teaching levels (0-5), from the initial to the expert, by setting concrete standards of language skills, abilities, and experience for each level. At all levels, the understanding of historical, politi-

\footnotetext{
${ }^{47}$ Chu D. S., DoD Regional Capabilities: The Way Ahead-Regional and Cultural Expertise: Building a DoD Framework to Meet National Defense Challenges White Paper, Department of Defense, Under Secretary of Defense, 2007, p. 9.

${ }^{48}$ Simakhov V. K., Cultural Competence and the Operational Level of War, Naval War College, 2013, p. 3.

${ }^{49}$ DOD Instruction 5160.70 Management of the Degense Language, Regional Expertise, and Culture (LREC)

Program, Office of the Under Secretary of Defense for Personnel and Readiness, 2016.

${ }^{50}$ Simakhov V. K., (footnote 48), p. 3.

${ }^{51}$ Publised in 2005 as „Gynybos kalbos programa“ (eng. Defense Language Program).

${ }^{52}$ Department of Defense Directive 5160.41E Defense Language, Regional Expertise, and Culture (LREC)

Program, 2015.
} 
cal, cultural, sociological, economic, and geographical factors of a foreign state or a specific region is mandatory. ${ }^{53}$ For example, military personnel with the initial level of regional skills, must know the main facts about the (mission) country, region or culture - the location, size, neighbouring countries, local language; have basic knowledge about the government of the mission country, main officials, religion, and history of the country, know the facts about the relations between the (mission) region and the USA, and also be familiar with the main norms of the country (for example, what they can do and what not). The knowledge can be acquired while attending classes about the region or country prior to the appointment or arrival in the mission country. ${ }^{54}$

Cultural exercises are mandatory for all military personnel, including troops in the reserve, and must be attended during the first year of their service. In the instruction, cultural exercises are divided into four constituent parts:

- diplomatic thinking/reasoning that covers the understanding of the importance for the mission of their own cultural perspective, cultural context, cross-culture relations, the ability to control one's own cultural standpoints and understand how military personnel are viewed by representatives of other cultures;

- cultural exercises that cover the cultural concepts and knowledge learned while preparing for cultural interaction, renewal of knowledge resting on the experience of others, search for experience and contacts in trying to improve the understanding about other cultures;

- cultural awareness that covers the ability to understand situations or environment and to control unexpected cultural behaviour, use the acquired knowledge while explaining situations, understand the cultural perspective other than one's own;

- cross-culture interaction that covers the involvement in cultural interaction with others, even if cultural actions, interaction, and its results are not known, the ability to develop and use alternative strategies in seeking the desired objectives as well as the capability to predict how representatives of other cultures will interpret and respond to certain actions, manners, and the attempt to communicate. ${ }^{55}$

At present, many cultural and language-teaching courses for military personnel are conducted in the Armed Forces of the USA; for example, the branch Captains Career Course, the Basic Officer Leader Course (BOLC-B), the Warrant Officer Advanced Course (WOAC), the Warrant Officer Basic

\footnotetext{
${ }^{53}$ DOD Instruction 5160.70, (footnote 49), p. 26.

${ }^{54}$ Ibidem, p. 29.

${ }^{55}$ Ibidem, p. 31-32.
} 
Course (WOBC), the Senior Leader Course (SLC), and the Advanced Leader Course (ALC). The objective of these courses is to develop the ability of military personnel to understand cultures and apply the obtained knowledge in the joint, inter-institutional, inter-governmental, and international environment by acquiring a sufficient level of competence in order to serve in a complex environment.

In addition to that, the Defence Language Institute Foreign Language Center (DLIFLC) renders assistance to the Army's Command and General Staff School (CGSS) in conducting language exercises before both deploying military personnel to an international operation and conducting professional language exercises. Both operational and strategic language exercises are carried out; for example, starting with 2006, before participating in the operations "Enduring Freedom", the "Iraqi Freedom", or the "New Dawn", all the officers of the USA Armed Forces could choose 48-hour language courses in Iraqi or Dari dialects. At the same time, strategic language exercises are also organized - the USA military personnel who are interested in acquiring life-long learning basics in the chosen languages can attend selective Chinese, French, Arabic, or Spanish language 48- or 72-hour courses. There is also a self-study possibility by using the Internet learning programs in 16 languages. ${ }^{56}$

It is necessary here to distinguish three main branches and officer career areas in the functional field where particularly great attention is devoted to cultural exercises; these being: special operations forces, psychological operations specialists, and specialists in civil affairs and foreign area officers (FAO). The requirements that troops of special operations forces must establish in-depth knowledge about at least one region of the world and professional language skills in at least one region. Good personal and cross-culture communication skills, political insights, and cultural sensitivity are also important because the success of the mission often depends on the ability of the troops of special operations forces to maintain the relationship and wield influence on the attitude and behaviour of foreign culture people. ${ }^{57}$ Specialists of psychological operations have to understand emotions, motives, and behaviours of a foreign audience; therefore, psychological operations specialists need regional, crossculture knowledge and professional language skills that they acquire not only while studying but also through operational experience. ${ }^{58}$ The tasks of specia-

\footnotetext{
${ }^{56}$ Sterilla A. Smith, "Army Culture and Foreign Language Program”, Military Intelligence Professional Bulletin, MIPB, Vol. 38, Nr. 1, January - March 2012, p. 8-12.

${ }^{57}$ Department of the Army Pamphlet 600-3, Commissioned Officer Professional Development and Career Management, Headquarters Department of the Army Washington, DC, 2014, p. 167.

${ }^{58}$ Ibidem, p. 179.
} 
lists in civil affairs make it necessary for them to get involved in, and make influence on, the civil populace while working with the local population and local institutions. Such specialists must have cross-culture communication skills, regional knowledge, language skills, and interpersonal skills. Until September 11, more than 95 percent of such specialists belonged to the army reserve, after September 11, these specialists were gradually transferred to the active forces. The program for teaching specialists that need to acquire regional and language skills lasts, on average, for two years. ${ }^{59}$ Foreign area officers should have a strategic attitude, regional competences, skills in foreign languages, and professional military area as well as experience. The training of these specialists lasts for more than four years. ${ }^{60}$

It is worth mentioning that lessons learned by the International Security Assistance Forces in Afghanistan encouraged the institutionalization of several supplementary cultural initiatives in the USA Forces. These being:

- Human terrain teams (HTT). The teams consist of 5-6 representatives and linguists of social sciences - anthropology, sociology, political sciences, and regional studies. The aim of the formation of Human Terrain Teams was to involve in warfare social science representatives advising senior officers on cultural issues and assisting in understanding the local populace in regions where these advisors serve. After the experimental variant of Human Terrain Teams proved worthwhile, in 2007, the Human Terrain Teams became one of the USA army programs and in 2010 it became permanent and was conducted until 2014. ${ }^{61}$

- Key Leader Engagements (KLE). This initiative represents the cooperation of military leaders with important leaders of the country where the international operation is conducted. The objective of these groups is not only to become engaged in short-term cooperation with local leaders in times of crises but also to establish long-term relationships and ensure the support of local leaders for the implementation of the interests of the armed forces.

- Female Engagement Teams (FET). The groups consist of female ISAF military personnel, the objective of which, in case of necessity, is to work with Afghanistan women because the communication and cooperation of male military personnel with Afghanistan women is not socially acceptable in the country.

\footnotetext{
${ }^{59}$ Ibidem, p. 189.

${ }^{60}$ Ibidem, p. 213.

${ }^{61}$ Kaiser S. S., (footnote 3), p. 17-18.
} 
- Company Intelligence Support Teams (CoIST). These groups, consisting of 2-6 military personnel, carry out the intelligence analysis of the location - the weather, the enemy, the relief, as well as the analysis of the impact of the local population on friendly operations - thus seeking to decrease the ambiguity and render assistance in the decision-making process. The aim of the Company Intelligence Support Team is to accelerate the flow of information and intelligence collection from company level to the higher headquarters. Each company member undergoes specialized training in how to gather information and carry out reconnaissance actions and is responsible for the generalization and submission of remarks and conclusions.

It is also worth mentioning that an effective and interesting initiative was the concept "one family - one soldier" during which the cultural awareness of military personnel was encouraged by acquiring information from a local family that lived in the country where the international operation was conducted and with whom the soldier socialized every day. ${ }^{62}$

\subsection{The Manifestation of Cultural Awareness in the United Kingdom}

In March 2007, the Armed Forces of the United Kingdom applied a specific doctrine for counterinsurgency operations (Engl. British Army Field Manual Volume 1 Part 10 Countering Insurgency). The importance of cultural awareness emphasized in the Doctrine essentially changed the training of military personnel participating in international operations. In 2007, the Armed Forces of the United Kingdom established an agency which is a part of the Directorate of Targeting and Information Operations (DTIO). The agency is responsible for the gathering and employment of the information related to culture and cultural norms in the international operation locations. One of the working groups of this agency is the Social and Cultural Profile Group, the main task of which is to determine the profile of the population inhabiting the territory of the international operation, foresee the cultural and cross-culture framework necessary for the training of military personnel prior to the international operation and prepare the analysis of cultural relations in the target regions. The primary structure responsible for cultural exercises and education

\footnotetext{
${ }^{62}$ Beljan R., "Afghanistan: Lessons Learned from an ISAF Perspective”, Small Wars Journal, May 30, 2013, http://smallwarsjournal.com/jrnl/art/afghanistan-lessons-learned-from-an-isaf-perspective, [2017-05-07].
} 
of military personnel is the Defence Cultural Support Unit (DCSU). This unit not only prepares troops for international operations but also performs a permanent mission - training cultural advisors (CULAD) participating in international operations and providing cultural development training to military personnel at diverse levels. ${ }^{63}$

The Joint Doctrine Note 1/09 of 2009 of the United Kingdom, underlines that cultural information should be available during the initial phases of military personnel training and cultural exercises and cultural education are core elements in seeking to understand "others with whom, amongst whom and against whom we operate". ${ }^{64}$ As it was mentioned in the first section, cultural capabilities are divided in the Note into three levels: cultural awareness, cultural understanding, and cultural competences. Cultural awareness exercises are mandatory for all military personnel, while those of cultural understanding are for the military involved in interactions with the local populace; for example, to the group of civil-military cooperation, security and stabilization commands, intelligence personnel. Exercises of the advanced level, those of cultural competences, are obligatory for cultural advisors. ${ }^{65}$ In 2011, a Guide for Defence Cultural Specialist Unit was published, which provides for cultural awareness exercises not only for culture specialists but also for all British military. This Guide raises two primary objectives: a) to prepare cultural advisors and b) to support cultural awareness exercises for military personnel who will conduct international operations abroad. The long-term objective is to acquaint all military personnel with the initial level of cultural exercises. ${ }^{66}$

In the United Kingdom, cultural awareness of the military is perceived as the synthesis of culture-specific language and cross-culture competences. This is confirmed by the definition of cultural capability from 2011 used in the Joint Doctrine Publication 2-00 "Understanding and Intelligence Support to Joint Operations". In this Doctrine, cultural capability is defined as the ability to understand culture and apply this knowledge by effectively engaging in another cultural environment. The Doctrine details that, for the acquisition of cultural capability, it is necessary to have not only knowledge about

\footnotetext{
${ }^{63}$ Dragomir I., "Military communication in intercultural contexts", Globalization, Intercultural Dialogue and National Identity. Conference, http://www.upm.ro/gidni3/GIDNI-03/Lds/Lds\%2003\%2088.pdf, [2017-07-10].

${ }^{64}$ United Kingdom Assistant Chief of the Defence Staff. Joint Doctrine Note 1/09: The Significance of Culture to the Military, (footnote 27), p. 5-1.

${ }^{65}$ United Kingdom Assistant Chief of the Defence Staff. Joint Doctrine Note 1/09: The Significance of Culture to the Military. Wiltshire, UK: Chief of Defence (Development, Concepts and Doctrine), January 2009, p. 1-2, p. 5A-2.

${ }^{66}$ Multinational Interoperability council coalition building guide, (footnote 6), p. B-3.
} 
the region where the international operation is going to take place but also the general awareness of soldiers about other cultures, as well as the understanding of how cultures make an impact on the understanding of the world. ${ }^{67}$ The United Kingdom's Joint Doctrine Publication 05, "Shaping a Stable World: the Military Contribution" of 2016, emphasizes that the understanding of culture and history, as well as the involvement in the process of army planning and training, increases the power of the armed forces ${ }^{68}$ and at the same time is an influence-wielding measure. The Doctrine states that "influence is achieved when we change the behaviour of the target audience. It is not just about messages or media, but about how the combination of the word and the deed are portrayed, interpreted and understood by audiences when viewed through the lens of their own culture, history, religion and tradition. Influencing is challenging and requires an understanding of target audiences." ${ }^{69}$

As mentioned before, in the United Kingdom cultural exercises are mandatory for all military before deploying them to an international operation. The duration of the teachings depends on the military unit and its specialization and lasts from one to several weeks. Although the greatest attention is devoted to the teaching of cultural advisors, alongside the change in the military doctrine of the United Kingdom, cultural development began to be regarded as part of the career of all military personnel. ${ }^{70}$ Cross-culture exercises, prior to the deployment of troops to an international operation, cover practical classes by paying attention to both cross-culture and culture-specific competences. ${ }^{71}$ The teaching takes two directions - All Ranks Briefing and two 45-minute sessions for tactical commanders. In addition to that, all the personnel planned for international operations, particularly those that deal directly with the local populace, have to undergo a Level 1 course for culture specialists that lasts one week and offers the personnel the knowledge about the country and the local culture where the operation is conducted. For the preparation of cultural advisors, who are linguists and use their regional experience advising military leaders on decision-making, the advanced cultural specialists program is used. The program consists of a two week long academic and culture-general course and a language course that lasts fifteen months. Before the end of the

\footnotetext{
${ }^{67}$ Joint Doctrine Publication 2-00 (JDP 2-00), 3rd Edition, Understanding and Intelligence Support to Joint Operations, The Development, Concepts and Doctrine Centre, Ministry of Defence, August 2011, p. 1-17. 
language course, cultural advisors have also to take exercises that last twelve weeks and are orientated towards the activity referring to crisis management, informational operations, and maintaining of relations. The teaching of cultural advisors finishes with a three-four week long course orientated towards culture-specific characteristics of a certain region, including the dominating power relations, economy, policy, religion, history, and similar aspects. Thus, the preparation of cultural advisors lasts on average twenty months. ${ }^{72}$

The United Kingdom, while participating in international operations, has imported from other states the concept of Female Engagement Groups that is popular in the USA while the concept of the Defence Cultural Specialist Unit rests on the model of the USA Human Terrain Teams. When the military personnel of the United Kingdom participated in the international operation in Afghanistan, the role of cultural specialists was the same as that of the USA Human Terrain Teams - they helped to identify and understand the local culture, political, social, economic, and historical environment. All of which assisted military leaders in making better and more informed decisions; additionally, advisors conducted cultural development of the troops in the mission location. The United Kingdom also encourages the sharing of the experience acquired during international operations among the military personnel. ${ }^{73}$

\subsection{The Manifestation of Cultural Awareness in Canada}

The main doctrine regulating cultural awareness and cultural exercises of the military is the Doctrine of the Canadian Defence Force's "Civil-Military Cooperation Tactics, Techniques and Procedures" published in 2006. This Guide emphasizes the requirement that in conducting civil-military cooperation operations it is necessary to have the understanding of the cultural context within which the troops are operating. The Guide "Cultural Intelligence and Leadership", published by the Canadian Defence Academy in 2009, encourages cultural intelligence that is defined as "the ability to recognize the shared beliefs, values, attitudes and behaviours of a group of people and, most importantly, to effectively apply this knowledge toward a specific goal or range of activities." Canada applies the USA concept of culture-general approach to the operational culture. In other words, military personnel must understand and articulate their own culture in developing the ability to identify and analy-

\footnotetext{
${ }^{72}$ United Kingdom Ministry of Defence, "Military Develops its Cultural Understanding of Afghanistan", Defence News, 24 February 2010.

${ }^{73}$ Trochowska K., (footnote 7), p. 96-97.
} 
se cultural differences during international operations. Critical thinking skills of this nature can be applied during different international operations for both understanding local cultures and improving relations with coalition or international partners. ${ }^{74}$

The Canadian Military Doctrine CFJP 0I accentuates the importance of cultural and religious development of the military prior to international operations. $^{75}$ In the Doctrine of Land Operations 2008 (B-GL-300-001/FP-001) combining and replacing the operational-level Canadian Force's Doctrine "Conduct of Land Operation - Operational Level Doctrine for the Canadian Army" (B-GL-300-001/FP-000) and the Land Force Tactical Doctrine (B-GL300-002/FP-000), particularly great attention is devoted to the cultural development of military personnel. The Doctrine reads that "cultural training of land forces, prior to and during a campaign, will ensure an appreciation and understanding of the local population. Cultural appreciation and understanding will include many aspects of a specific culture such as ethnic heritage and religion. While cultural appreciation will identify a culture's visible landmarks, cultural understanding is more in-depth knowledge of the power structures that are essential to develop operational or tactical level plans. $<\ldots>$ Cultural understanding may hold critical importance in situations in which the local populace is a key factor or even the center of gravity. $<\ldots>$ The success of most operations will ultimately depend upon the continued support of the civilian population" ${ }^{76}$ The local populace in this Doctrine is seen as one of the essential elements of the operational environment the understanding and cognition of which enable to achieve the desired goals. ${ }^{77}$

Cultural awareness exercises of the military in Canada last on average six weeks. The greatest part of the training is conducted by the Peace Support Training Centre. Though the themes of the training depend upon the international operation, military ranks and positions held by the military personnel, all the troops are instructed in the basic rules of behaviour in another cultural environment. Military personnel of a higher rank undergo teaching of a broader spectrum, covering the history of the country where the international operation is conducted, with varied nature simulations; for example, a part

\footnotetext{
${ }^{74}$ Davis K., ed. Cultural Intelligence and Leadership: An Introduction for Canadian Forces Leaders. Kingston, ON: Canadian Defence Academy Press, 2009

${ }^{75}$ Canadian Military Doctrine CFJP 01, Canadian Forces Joint Publication, Issued on authority of the Chief of the Defence Staff, 2009-04, p. 6-4.

${ }^{76}$ Chief of the Land Staff, Land Operations, B-GL-300-001/FP-001, Army Publishing Office, Fort Frontenac, Kingston, Ontario, p. 2-7.

${ }^{77}$ Ibidem, p. 2-2.
} 
of cross-culture exercises were conducted in simulated Afghanistan villages built while taking a realistic environment of the exercises into consideration. ${ }^{78}$ While conducting an international operation in Afghanistan, the Training Centre organized a five-day-long cultural awareness course orientated towards general understanding of the country of the international operation. For example, when the Canadian forces were deployed in the southern part of Afghanistan, cultural awareness exercises were orientated toward the Kandahar Province and Pashto dialect. When Canadian forces were redeployed to Kabul and Northern Afghanistan, the training was adapted to a more generalized Afghanistan approach, including the teaching of Dari and Pashto dialects. The cultural training of the Canadian Forces rests on interactive classes and the experience of the military that participated in missions. In such classes at least one member from the Cross-culture Training Centre and one expert from the country of the international operation most often participate. Country experts most frequently originate from the country where the international operation is conducted and have a personal experience of living and/or working in the mission country. These experts work with international forces as language advisors of the mission country. ${ }^{79}$

Canada has also imported cultural development experience from other states: while training military personnel, they refer to the decisions of the cross-culture exercises of the United Kingdom; hire instructors from the United Kingdom; military personnel use the services of cultural advisors and interpreters during international operations; have White Situational Awareness Teams built according to the model of the USA Human Terrain teams. Also, after an international operation, military personnel share the acquired experience with other military personnel while teaching programs are renewed after each deployment of the military. ${ }^{80}$

\subsection{The Manifestation of Cultural Awareness in Lithuania}

In Lithuania, the first initiative in carrying out cultural awareness training was the agreement between the Ministry of National Defence and the Center of Oriental Studies of Vilnius University signed in May 2005. On the grounds of this agreement, language teaching for military personnel leaving

\footnotetext{
${ }^{78}$ Trochowska K., (footnote 7), p. 96-97.

${ }^{79}$ Gates K. D., Applying Culture to Military Operations: A Review of Foreign Militaries, USMC Command and Staff College, Master of Military Studies Research Paper, 2012, p. 21-25.

${ }^{80}$ Trochowska K., (footnote 7), p. 96-97.
} 
for international operations in Afghanistan began. The agreement was shortlived because language proficiency of the instructors teaching language skills to the military was not sufficient for the appropriate preparation of military personnel. The second initiative was the agreement of 2005 between the General Adolfas Ramanauskas Combat Training Centre of the Lithuanian Armed Forces and the Centre of Multi-Cultural Relations. Academicians, experts in Islam and the Middle East working in this Centre and having language skills in Farsi and Arabic, conducted teaching in both culture and language. However, the insufficient interest of the Ministry of National Defence to continue the cultural awareness teaching of military personnel, as well as a shortage of financing, resulted in stopping this activity and returning to the support of NATO allies in teaching military personnel as well as to the mutual learning by sharing the experience of the military that participated in previous missions. ${ }^{81}$ The informal learning of military personnel, as well as sharing of photos, experience, impressions, and materials filmed during the international operation, became a new stimulus in formalizing cultural training - the Ministry of National Defence expressed an aspiration to establish a centre where the military personnel, after returning from an international operation, could systematize their experience and knowledge as well as impart them to other military personnel going to international operations. At the same time, seeking to enhance the cultural awareness of the military, in 2006, acting on the initiative of the Ministries of National Defence and Foreign Affairs, a guide for the province of Ghor describing the historical, geographic, economic, social and security situation in Afghanistan was prepared. The extent of the Guide was particularly small, not detailed; therefore, the Lithuanian military guided themselves by the Guide to Afghanistan used by the USA military personnel with limitations applicable to the Ghor Province because of differences in ethnic, religious, and social groups in different provinces of Afghanistan. ${ }^{82}$

In 2011, the Operational Doctrine of the Lithuanian Armed Forces assessed anew the importance of the cultural development of military personnel. The Doctrine pays great attention to the cultural awareness of the military and stresses the importance of cooperation between military personnel and their partners " $<\ldots>$ Mutual respect for professional capabilities of partners, culture, history, religion, customs and values enhance cooperation $\langle\ldots$..” and the cognition of the enemy: " $<\ldots>$ In international operations, it is necessa-

\footnotetext{
${ }^{81}$ Račius E., "The 'Cultural awarenes' factor in the activities of the Lithuanian PRT in Afghanistan", (24 footnote), p. 69-70.

${ }^{82}$ Ibidem, p. 73.
} 
ry to have information not only about the friendly forces but also about the enemy" ${ }^{83}$ The Doctrine also emphasizes that the first operational problem of international operations is related to the knowing of the local population of the country where the international operation is conducted: "First, the operational problem $\langle\ldots\rangle$ is characterized by the fact that the opponent can operate against multinational operational forces (or their units) in small groups $\langle\ldots\rangle$, employ irregular tactics, mixed weapons, improvised explosives, suicides, the global press and other measures $\langle\ldots\rangle$ and conducts operations which are partly supported by the local population (local culture) $<\ldots>>{ }^{84}$ In the Doctrine, cultural differences are defined as "the essential factors influencing the planning and execution of international operations", ${ }^{85}$ while one of the most important contributions of this Doctrine to the cultural awareness of military personnel is the distribution of responsibility while culturally training the military foreseeing that specialists in civil-military cooperation who "possessing themselves cultural competences should encourage military personnel to take interest in and respect the culture, traditions of another country and perceive how important it is to work together with civilian subjects" ${ }^{86}$ as well as the definition of cultural competences is for the first time established while defining them as "the understanding of traditions and history of the local populace and civilian entities functioning in the theatre of operations and respect accorded to their way of life". ${ }^{87}$

The Lithuanian Armed Forces Training Doctrine 2013 and The Lithuanian Military Doctrine 2016 do not elaborate on the cultural development of the military issue. In the Doctrine of 2013, cultural awareness is related only to the cognizance of the operational environment, stating that: " $<\ldots>$ in order to understand the operational environment, we have to analyse objective factors that change the conditions of the operational environment and simultaneously have influence on the execution of current and future operations, the teaching of military personnel $\langle\ldots\rangle$ as well as training of forces (units). These factors can be but are not limited to: 1 . The diversity of cultures, ideologies and social

\footnotetext{
${ }^{83}$ Lietuvos karinių pajègų operacinè doktrina, D-LK-002, Antrasis patikslintas leidimas, patvirtinta Lietuvos kariuomenès vado $2011 \mathrm{~m}$. kovo 10 d. įsakymu Nr. V-230, 2011, http://www.lietuvoskariuomene. lt, p. 1-17.

${ }^{84}$ Ibidem, p. 2-33.

${ }^{85}$ Ibidem, p. 3-32.

${ }^{86}$ Ibidem, p. 5-40.

${ }^{87}$ Ibidem, p. 5-40.
} 
structures" ${ }^{88}$ In the Doctrine of 2016, cultural awareness is accentuated as one of the necessary competences underlying that: "the nucleus of the armed forces is formed from the motivated initiative of firm combat spirit and well-trained (particularly psychologically) military personnel $<\ldots>$ capable of operating in a multinational and multicultural environment", ${ }^{89}$ and also " $<\ldots>$ a warrior of the 21st century distinguishes himself by: $\langle\ldots\rangle$ cultural and legal awareness $\langle\ldots\rangle$ the ability to operate in a multinational, multicultural, interinstitutional, interorganizational, and interstate environment". ${ }^{90}$ It should be noted that the Doctrine does not detail what should be considered as cultural awareness.

Surveying the regulation of the implementation of the military personnel's cultural awareness in the Orders by the Commander of the Lithuanian Armed Forces, one can note that the military are differentiated according to the specifics of their work - the greatest need of cultural awareness is applied to civil-military cooperation specialists and specialists of psychological operations. On the list of individual tasks and performance standards of the civil-military cooperation group/team, three tasks developing cultural awareness are detailed: " 1 . To understand the diversity of traditions and cultures, be able to distinguish the main differences in cultural activities in various areas of operations $\langle\ldots>2$. The military person should be familiar with the existing world religions, be able to distinguish the main religions and potential influences in areas of operations and $\langle\ldots\rangle$ 3. To know the particulars of the interpreter's work and be able to practically work through an interpreter during meetings". ${ }^{11}$ In the program of the Civil-Military Cooperation Course that was prepared in 2017 but has not yet been approved, the cognizance of religion is crossed out from the list of tasks that military personnel have to perform. The analysis of the influence of culture and gender aspects on international operations is given two theoretical academic hours, for the development of skills of working through the interpreter one theoretical and one practical academic hour are allotted. ${ }^{92}$

High cultural awareness requirements are also set for specialists of psychological operations. These specialists should be able to "carry out rese-

\footnotetext{
${ }^{88}$ Lietuvos karinių pajègų rengimo doktrina, D-LK-07 (patikslinta redakcija), patvirtinta Lietuvos kariuomenès vado 2013 m. balandžio 4 d. įsakymu Nr. V-376, 2013, http://www.lietuvoskariuomene.lt, p. 8-1.

${ }^{89}$ Lietuvos karinè doktrina, D-LK-1, antrasis leidimas, patvirtinta Lietuvos kariuomenès vado $2016 \mathrm{~m}$. balandžio 22 d. ịsakymu Nr. V-570, Lietuvos kariuomenès Karo kartografijos centras, 2016, p. 6-1.

${ }^{90}$ Ibidem, p. 8-3.

${ }^{91}$ Lietuvos kariuomenės vado 2010 m. gruodžio 27 d. įsakymas Nr. V-1160 „Civilių ir karių bendradarbiavimo būrio/komandos individualių užduočių sąrašas ir atlikimo standartai (sausumos pajègos).“

${ }^{92}$ Lietuvos kariuomenès sausumos pajėgų Juozo Lukšos mokymo centras, Civilių ir karių bendradarbiavimo kursas, Mokymo programa, JLMC - L7 - 070.
} 
arch of a country (state) by referring to political-military analysis", also including the analysis of culture, language, values, faith and behaviour, religion, social organizations as well as be able to work through interpreters. ${ }^{93}$ Notwithstanding, the Order does not detail how psychological operations specialists' analytical skills enabling them to carry out the analysis of a target state are developed and how many hours are allotted for the teaching of such specialists.

In Lithuania, contrary to the other analysed states, the differentiation of cultural awareness exercises according to the military rank is limited. Such differentiation can be found only in the teaching programs of career NCOs; for example, in the program of the NCO Stage III Career Course regulating the training of warrant officers and major sergeants, one of the set teaching objectives is "To understand how different management styles are affected by different cultures"; the objective is split into several tasks: "1.To explain management styles; 2 . To discuss the application of management styles; 3 . To explain what a culture is; 4 . To explain the typology of cultures". One more objective is set for the NCOs of this level: "to understand how management styles are applied in international military operations" by being able "to discuss cultural aspects that have an impact on operations". For the implementation of these two objectives, four academic hours are allotted. ${ }^{44}$ The program of the NCO Stage II Career Course regulating the training of senior sergeants and staff sergeants states that one of the tasks set for this chain of military personnel is "to understand the impact of ethical and unethical decision on military operations", through imposing these tasks: "1. To compare the influence of ethical and unethical decision on military operations; 2 . To define challenges of ethics wielding influence on decision-making and their impact on operations; 3 . To explain what a culture is; 4 . To explain the areas covering culture; 5 . To discuss what influence cultural awareness can have on the success of the operation." Two academic hours are allotted for the implementation of the objective. ${ }^{95}$ The program of 2014 of the NCO Stage I Career Course regulating the training of privates 1st class and sergeants, states that military personnel should "know the main attributes of cultural differences" and "understand the importance of the development of cultural awareness and its influence on the success of the

\footnotetext{
${ }^{93}$ Lietuvos kariuomenès vado 2011 m. gruodžio 8 d. įsakymas Nr. V-1255 „Psichologinių operacijų specialisto individualių užduočių atlikimo standartai“, p. 3.

${ }^{94}$ Lietuvos kariuomenès vado 2015 m. lapkričio 20 d. ̨̣sakymas Nr. V-1415 (Lietuvos kariuomenès vado 2016 m. spalio 17 d. ịsakymo Nr. V-1419 redakcija),,Puskarininkių karjeros III pakopos kurso (LKML7-1103) mokymo programa."

${ }^{95}$ Lietuvos kariuomenès vado $2014 \mathrm{~m}$. rugsèjo 15 d. ịsakymas Nr. V-912 (Lietuvos kariuomenès vado 2017 m. sausio 18 d. įsakymo Nr. V-58 redakcija) „Puskarininkių karjeros II pakopos kurso (LKM-L7-1102) mokymo programa."
} 
operation". ${ }^{96}$ Notwithstanding, in the renewed program of the NCO Stage I Career Course, cultural cognizance is eliminated as a mandatory teaching subject for the military personnel of this chain. ${ }^{97}$ It should be pointed out that in the NCO teaching programs of either Stage I or Stage II, there are no indications upon what cultural awareness definition the teaching is based.

In officers teaching programs, cultural awareness trainings are not specially regulated. Limited elements of training can be detected in the teaching programs for cadets - future officers; for example, cadets studying at the General Jonas Žemaitis Military Academy of Lithuania have a 48-hour-long elective "cross-cultural communication" course; also, a number of cadets, specifically those studying International Relations, are familiarized with regional studies.

The training of military personnel of all ranks is at present regulated by "the Training Course for the Military Personnel going on International Operations (individual skills renewal course)". The teaching objective of the course is: "To know the history of the international operation country, cultural, and religious specificities of the region"; The tasks for implementing this objective are: "1.To describe culture, traditions, religion, political and economic situation, geography, climate, population, history, the development of the conflict and the military situation of the future operation area; 2 . To define peculiarities of communication with the local population; 3 . To define differences and similarities between Islam and Christianity". For the achievement of this teaching objective, three hours of theoretical classes are planned. One more objective set for military personnel is: "To understand basic principles of working through an interpreter" and the given task is: "To enumerate basic principles of working through an interpreter". For the implementation of this task, one hour of theoretical classes is allotted. The teaching of dominate languages in the areas of international operations for military personnel is not conducted..$^{98}$

It should be noted that in Lithuania, there is no single institution or military subunit that conducts cultural exercises for the military - cultural awareness of civil-military cooperation specialists is developed by Juozas Lukša Training Centre of the Lithuanian Land Force; that of non-commissioned officers

\footnotetext{
${ }^{96}$ Lietuvos kariuomenès vado 2014 m. rugsèjo 29 d. įsakymas Nr. V-979 „Puskarininkių karjeros I pakopos kurso (LKM-L7-1101) mokymo programa.“"

${ }^{97}$ Lietuvos kariuomenès vado 2014 m. rugsèjo 29 d. ịsakymas Nr. V-979 (Lietuvos kariuomenès vado 2016 m. rugpjūčio 5 d. İsakymu Nr. V-1107 redakcija) „Puskarininkių karjeros I pakopos kurso (LKM-L7-1101) mokymo programa."

${ }^{98}$ Lietuvos kariuomenès vado 2016 m. kovo 9 d. įsakymu Nr. V-342 „Karių rengimo tarptautinėms operacijoms (individualių igūdžių atnaujinimo kursas (KRC - L7 - 001).“
} 
by Division General Stasys Raštikis Lithuanian Armed Forces School; cadets' cultural awareness is conducted by the General Jonas Žemaitis Military Academy of Lithuania and that of military personnel to be sent to international operations by General Adolfas Ramanauskas Combat Training Centre of the Lithuanian Armed Forces. Attention should also be paid to the fact that in all the analysed documents regulating cultural awareness of Lithuanian military personnel, cooperation of military units by exchanging, between themselves, the cultural experience of warriors or mastering the experience of other NATO states is not encouraged or declared in any other way.

\section{General Conclusions of the Research}

Having analysed the manifestation of the cultural teaching of military personnel in military doctrines and other documents regulating the activity of the armed forces and military service in the USA, the United Kingdom, Canada, and Lithuania, it is possible to confirm the hypothesis proposed in the article - during the research, it became clear that in all the analysed states, in the institutionalized cultural awareness exercises of military personnel, a great attention is devoted not only to the cultural development of the military irrespective of the depth of the involvement of major NATO states in international operations (for comparison, from the analysed states which institutionalized cultural teaching of military personnel, the largest number of troops sent to international operations belongs to the USA - 210,000, the smallest one - to Canada - 1,450) but cultural teaching is also regulated in a rather similar way. In all the states that institutionalized cultural awareness of the military, cultural awareness exercises reflect the cultural awareness comprising competences distinguished in the theoretical model, i.e. in the USA, the United Kingdom, and Canada, cultural development of military personnel covers the acquisition of culture-specific, cross-culture, and language competences. One can state that in these states, cultural awareness of the military is seen as a long-term comprehensive process. Such a premise is based on the inclusion of cross-cultural competences in the teaching programs of the armed forces. The development of culture-specific competences prepares military personnel only for an exceptionally certain international operation - military personnel are familiarized with the information of a specific culture, state or region. The development of cross-culture competences enhances the adaptive skills of the military irrespective of the cultural environment; therefore, military personnel can get more easily accustomed, not only to the changing context of inter- 
national operations, but also while working in a coalition with international partners.

Still more common features can be distinguished while conducting cultural exercises of military personnel in the states that institutionalized cultural awareness of troops. First, in the USA, the United Kingdom, and Canada, interactive teaching methods are used and military personnel are involved in the teaching process. Second, in these states, while preparing culturally aware military personnel and familiarizing them with other cultures, a stage-based approach is applied - cultural awareness exercises of military personnel are differentiated, taking into account the activity carried out by military personnel, the positions held, or military ranks. Senior officers are often given a broader-scope at the same time committing them to teach their subordinates. In addition to that, during international operations, cultural exercises are supplemented with the assistance of cultural advisors who help senior officers in decision-making. Third, cultural awareness teachings of military personnel are not short-term, ad hoc initiatives, cultural development is organized and coordinated by institutions or cultural development schools established for that purpose while cultural awareness is treated as a part of a life-long learning concept. Finally, it can be noted that the analysed major NATO states that institutionalized cultural awareness not only take over each other's experience in developing culturally aware military personnel but also constantly improve cultural exercises, taking into consideration previous rotations of military personnel, while troops are encouraged to share the acquired experience between themselves. It is worth mentioning that differences among the states that institutionalized the cultural development of the military are, in essence, of only a technical nature - for example, contrary to other analysed states, the USA encourages an independent, self-perfection of troops by getting involved in cultural distance learning. Besides, minor differences in the duration of teaching are noted, initiatives that emerged while states participated in international operations supplementing cultural teaching also vary slightly, furthermore, in the military doctrines, some states base their activity on the definition of a non-hierarchized cultural awareness while others - on the hierarchized one.

While comparing the manifestation of cultural awareness in military doctrines and other documents regulating the activity of armed forces and military service of Lithuania and other analysed NATO states, these remarks are made in terms of the cultural development of Lithuanian military personnel. First, only a slight attention to the importance of the cultural development of military personnel carried out in Lithuania is marked by the absence of 
cultural awareness standardization in military doctrines, as well as between different subunits of the Lithuanian armed forces. Though in 2011, in the Operational Doctrine of the Lithuanian Armed Forces, the definition of cultural competences was established, however in the Lithuanian Military Doctrine of 2016 the definition of cultural awareness functions while in the NCO Stage I and Stage II Career teaching programs, the definition of cultural consciousness appears. It is worth noticing that the concepts of either cultural awareness or cultural consciousness are not defined in these documents. The absence of cultural awareness standardization in the strategic documents of the Lithuanian armed forces make the implementation of cultural awareness in practice more difficult - the interpretation of cultural awareness depends on the teaching instructors and the competences they have. Thus, it is possible to make the assumption that the diversity of the definitions used might create grounds for the emergence of the problem related to the standardization of the definition of cultural awareness; the problem for which the USA Armed Forces have been criticized for a long time - different USA Army subunits interpreted cultural awareness teaching of military personnel individually and eventually the problem of the harmonization of cultural awareness teaching surfaced. At present, Lithuania is potentially following this practice - different subunits of the armed forces do not cooperate between themselves in conducting cultural teaching of the military and this only confirms the insufficient evaluation of the importance of cultural development in shaping the Defence Policy of Lithuania.

It is worth noting that, on the grounds of the experience of major NATO states that institutionalized cultural awareness of the military personnel, in developing cultural awareness of the military in these states in terms of the positions held by the military personnel or their military ranks the differentiation of teaching is always applied. In Lithuania, taking into consideration military ranks, elements of the limited differentiation can be observed: for lower chain military personnel, specifically for non-commissioned officers, relatively more cultural trainings are conducted than for officers. The practice of other NATO states when a broader-spectrum cultural teaching is conducted to platoon commanders and other higher-rank officers who will share the acquired experience with their subordinates is not applied in Lithuania. The differentiation of cultural awareness teaching, in terms of the positions held by the military personnel, is also poor. Though in the Operational Doctrine of the Armed Forces of Lithuania 2011, a great responsibility in developing culturally aware military personnel is assigned to the specialists of civil-military cooperation, 
however, in the teaching program of the Civil and Military Cooperation Course, prepared in 2017, culture-specific and working-through-the-interpreter teaching are allotted only four academic hours. It should also be noted that even the military personnel having the greatest need for cultural awareness, specifically specialists in civil-military cooperation and specialists in informational operations are not taught the languages dominate in the country of the international operation.

It is worthwhile to pay attention to the methods and duration of military personnel teaching. In NATO states that institutionalized cultural awareness of military personnel, the minimal duration for the acquisition of culture-specific competences prior to an international operation is at least a several-daylong course. The duration of the training of military personnel in cross-cultural competences can amount to several years. In Lithuania, four academic hours on average are devoted to the development of cultural awareness: 2-3 hours for culture-specific and 1-2 hours for working through the interpreter competences. The employed developmental methods are also potentially insufficient for the adequate preparation of military personnel, for example, the program of "Training Course for the Military Personnel going on International Operations (individual skills renewal course)" provides for exceptionally theoretical lectures on the development of cultural awareness of military personnel. On the grounds of the experience of the USA, the United Kingdom, and Canada, the system of lectures should be supported by the involvement of military personnel in the teaching process: seminars, discussions, simulation and role-playing games, and distance learning, in addition to theoretical lectures, because cultural teaching comprises interdisciplinary skills that are not acquired by just listening to lectures.

One of the most important strategic-level problems of the cultural awareness of Lithuanian military personnel caused by both the lack of cultural awareness standardization and the potential shortage of attention to the cultural development of the military is the problem of the interpretation of competences covering cultural awareness. It turned out in the theoretical model that for the cultural awareness of military personnel participating in international operations, the acquisition of culture-specific, cross-cultural, and language competences is mandatory. The analysed major NATO states only confirmed this tendency - in all the analysed states, irrespective of the scope of their involvement in international operations, cultural teaching covers the acquisition of all these competences. Notwithstanding, the development of cross-cultural competences is not reflected in any of the Lithuanian military 
doctrines or in other documents regulating the activity of the armed forces and military service. This enables the author to state that on the grounds of both the theoretical model of competences and the experience of major NATO states, the Lithuanian military personnel acquire only a part of competences necessary for them and consequently, warriors having limited cultural awareness are trained. The acquisition of culture-specific competences practised in Lithuania is orientated towards short-term ambitions - military personnel are trained for an exceptionally specific international operation while the acquired skills are not adapted to the changing spectrum of international operations. If cross-culture competences were included into the teaching programs, adaptive skills of the military personnel would be developed in Lithuania on a broad scale (while both cooperating with coalition partners and participating in international operations) and this, in its turn in the long-term perspective, would make the acquisition of culture-specific competences easier. It is worth mentioning that by the development of cross-culture competences, Lithuania devalues the importance of cultural cooperation with partners - the development of culture-specific competences is orientated exceptionally towards the cognizance and attraction of the society of the state where the international operation is conducted but not towards the development of smoother cooperation with coalition partners.

It is reasonable to think that Lithuania can and must align itself with major NATO states in developing the framework of cultural awareness in strategic documents and development programs. The carried out analysis made it clear that irrespective of the scope of states' involvement in international operations, the cultural development of military personnel conducted in major NATO states has many common tendencies; on the contrary, in Lithuania a considerable breaking-off from the states that institutionalized cultural development of military personnel is noticeable. Lithuania faces problems that cannot be justified by a small number of military personnel sent to international operations since it has already turned out that the involvement in international operations has no influence on the regulation of cultural awareness of military personnel or by the lack of resources. The main problems that Lithuania encounters are not susceptible to resources; they are problems of the interpretation and standardization of cultural awareness, the inexpedient differentiation of teaching, non-cooperation of military units between themselves, and imperfection of cultural training concerning the previous participation of the military in international operations. They are problems emerging because of the insufficient evaluation of the importance of cultural development and lack 
of attention to cultural aspects in shaping the Defence policy of Lithuania. It is possible to state that cultural development of military personnel is the evaluation of Defence policy shapers' attitude towards the importance of cultural aspects in warfare. Major NATO states demonstrate unanimity on this issue, even if there is no cultural awareness regulation at the NATO level. A change in the attitude to the cultural development of the military at the strategic level, taking into account the experience of major NATO states, could become the first step in improving the manifestation of cultural awareness of military personnel in military doctrines and other documents regulating the activity of the armed forces and military service of Lithuania.

September 2017 